\title{
PENGARUH DISIPLIN KERJA, MOTIVASI KERJA DAN LINGKUNGAN KERJA TERHADAP KINERJA PEGAWAI DI BADAN PENDAPATAN PENGELOLAAN KEUANGAN DAN ASET DAERAH KABUPATEN GRESIK
}

\author{
WAHYU DWI KURNIAWAN
}

Progam Studi Manajemen

Fakultas Ekonomi- Universitas Muhammadiyah Gresik

Jl. Sumatra No. 101 GKB Gresik 61121 Jawa Timur Indonesia

\begin{abstract}
ABSTRAK
Tujuan Penelitian ini untuk mengetahui disiplin kerja, motivasi kerja dan lingkungan kerja terhadap kinerja pegawai di badan pendapatan pengelolaan keuangan dan aset daerah kabupaten gresik. Sampel menggunakan teknik probability sampling jenis propotionate stratified random sampling sebanyak 72 responden. Teknik analisis data menggunakan regresi linear berganda. Hasil analisis regresi linear berganda membuktikan bahwa disiplin kerja, motivasi kerja dan lingkungan kerja terbukti mempunyai pengaruh yang signifikan secara parsial terhadap kinerja pegawai di badan pendapatan pengelolaan keuangan dan aset daerah kabupaten gresik. Secara simultan disiplin kerja, motivasi kerja dan lingkungan kerja juga terbukti berpengaruh signifikan terhadap kinerja
\end{abstract}

Kata Kunci : Disiplin Kerja, Motivasi Kerja dan Lingkungan Kerja.

\section{PENDAHULUAN}

Sebagai unsur pelaksana otonomi daerah, Badan Pendapatan Pengelola Keuangan, dan Aset Daerah Kabupaten Gresik memiliki tugas pokok melaksanakan urusan pemerintahan daerah berdasarkan asas otonomi dan tugas pembantuan di bidang pendapatan, pengelola keuangan dan aset daerah. Untuk itu Badan Pendapatan, Pengelolaan, Keuangan dan Aset Daerah Kabupaten Gresik akan bekerja secara maksimal dan memberikan pelayanan terhadap masyarakat.

Menurut Sutrisno $(2014 ; 151)$ bahwa kinerja adalah sebagai hasil kerja yang telah dicapai seseorang dari tingkah laku kerjanya dalam melaksanakan aktivitas kerja. Kinerja pegawai merupakan sebagai hasil kerja secara kualitas dan kuantitas yang dicapai oleh seseorang pegawai dalam melaksankan tugasnya sesuai tanggung jawab yang diberikan kepadanya, Mangkunegara $(2005 ; 10)$. Fenomena menarik di lapangan terjadi peningkatan kinerja dari instansi pemerintah oleh para pegawainya. Berikut ini adalah gambar 1.1, menggambarkan tentang terjadi peningkatan kinerja dari Tahun 2010-2013.

Berdasarkan data pada gambar 1.1 menunjukkan bahwa dari mulai tahun 2010 2013 kinerja pegawai Badan Pendapatan Pengelolaan Keuangan dan Aset Daerah Kabupaten Gresik terjadi peningkatan kinerja dalam pencapaian target, pada tahun 2010 target yang diinginkan 65.460.199.000 sedangkan yang terealisasi 72.36.828.278. Pada tahun 2011 target yang diinginkan
117.069.696.051 sedangkan yang terealisasi 135.091.751.487. Pada tahun 2012 target yang diinginkan 211.633.950.000 sedangkan yang terealisasi 252.405.752.928. Pada tahun 2013 target yang diinginkan 266.600.000.000 sedangkan yang terealisasi 287.204.002.798.

Gambar 1.1 Data Rekapitulasi Target dan Realisasi Pajak Daerah pada Badan Pendapatan, Pengelolaan Keuangan dan Aset Daerah Kabupaten Gresik Tahun 2010-2013.

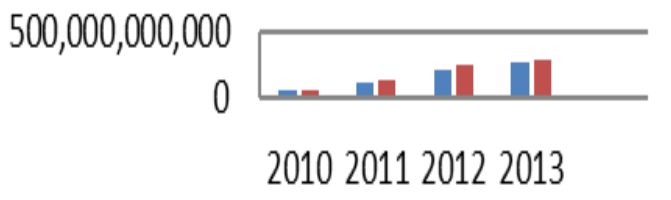

\section{-Target —Realisasi}

Sumber :DPPKAD Kabupaten Gresik

Menurut Simanjuntak $\quad(2011 ; 11)$ menjelaskan Kinerja seseorang di pengaruhi oleh banyak faktor yang dapat di golongkan pada 3 (tiga) kelompok yaitu kompensasi individu orang yang bersangkutan, dukungan organisasi, dan dukungan manejemen. Disiplin adalah sikap kesediaan dan kerelaan seseorang untuk mematuhi dan mentaati norma-norma peraturan yang berlaku di sekitarnya (Singodimedjo dalam Sutrisno, 2014;86).

Disiplin kerja dapat mempengaruhi kinerja pegawai Badan Pendapatan Pengelolaan Keuangan dan Aset Daerah Kabupaten Gresik, 
pernyataan ini diperkuat dengan adanya pendapat dari Hasibuan (2011;193) menyatakan bahwa semakin baik disiplin karyawan, maka semakin tinggi prestasi kerja yang dapat dicapainya. Berikut ini adalah Gambar 1.2, yang menggambarkan tentang Kehadiran kerja pegawai Badan Pendapatan, Pengelolaan Keuangan dan Aset Daerah Kabupaten Gresik.

Gambar 1.2 Data Rekapitulasi Kehadiran Pegawai BPPKAD Kabupaten Gresik Bulan Januari-April 2016

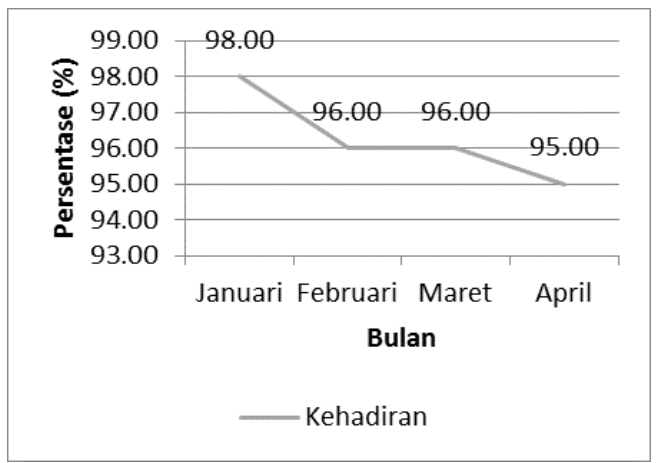

Sumber :DPPKAD Kabupaten Gresik

Berdasarkan data pada gambar 1.2 kehadiran pegawai di Badan Pendapatan Pengelolaan Keuangan dan Aset Daerah Kabupaten Gresik menunjukan penurunan dari Bulan Januari sampai dengan Bulan April. Ketidak hadiran disini adalah pegawai yang tidak masuk tanpa izin/alpa. Tingkat kehadiran semakin menurun menunjukan disiplin pegawai di Badan Pendapatan Pengelolaan Keuangan dan Aset Daerah Kabupaten Gresik semakin turun.

Selain disiplin, motivasi untuk bekerja ini sangat penting bagi tinggi rendahnya produktivitas perusahaan. Tanpa adanya motivasi dari para karyawan untuk bekerja sama bagi kepentingan perusahaan, maka tujuan yang telah ditetapkan tidak akan tercapai. Sebaliknya, apabila terdapat motivasi yang tinggi dari para karyawan, maka hal ini merupakan suatu jaminan atas keberhasilan perusahaan dalam mencapai tujuannya. (Gitosudarmo dalam sutrisno, 2014;111).

Menurut Mangkunegara (2009;93) motivasi adalah kondisi yang menggerakkan pegawai agar mampu mencapai tujuan dari motifnya. Berdasarkan hasil pengamatan di Badan Pendapatan, Pengelolaan Keuangan dan Aset Daerah Kabupaten Gresik terlihat adanya pemberian motivasi kerja yang diperkuat dengan penjelasan Haris, selaku sub.bagian program dan pelaporan bahwa di Badan Pendapatan, Pengelolaan Keuangan dan Aset Daerah Kabupaten Gresik menerapkan sistem evaluasi setiap bulan kepada pegawai terhadap pemungutan pajak daerah, evaluasi tersebut dilaksanakan untuk mengamati apakah pemungutan pajak daerah telah mencapai target yang telah ditetapkan. Menurut Bambang Sayogyo selaku Kepala Bidang Penetapan Badan Pendapatan, Pengelolaan Keuangan dan Aset Daerah Kabupaten Gresik pemberian motivasi kerja disini dengan memberikan teguran secara lisan

kepada pegawai apabila tidak mencapai target yang telah ditetapkan.

Selain disiplin, motivasi dan Lingkungan kerja adalah segala sesuatu yang berhubungan langsung dengan karyawan atau pekerja. Baik secara fisik maupun non fisik yang mempunyai dampak langsung kepada para pekerja atau karyawan terhadap tugas - tugas yang diberikan oleh perusahaan (Dewi dan Frianto, 2013).

Menurut Sedarmayanti (2009;21) lingkungan kerja adalah keseluruhan alat perkakas dan bahan yang dihadapi, lingkungan sekitarnya di mana seseorang bekerja, metode kerjanya, serta pengaturan kerjanya baik sebagai perseorangan maupun sebagai kelompok. Berikut ini adalah Tabel 1.1, yang menggambarkan Sarana dan Prasarana di Badan Pendapatan, Pengelolaan Keuangan dan Aset Daerah Kabupaten Gresik.

Berdasarkan data pada tabel 1.2 Sarana dan Prasarana di Badan Pendapatan, Pengelolaan Keuangan dan Aset Daerah Kabupaten Gresik yang memliki kondisi yang lengkap dan baik yaitu : Monitor, AC, Lemari, Proyektor. Sedangkan yang lain mengalami kondisi yang kurang baik dan tidak lengkap.

Berdasarkan uraian diatas maka peneliti merasa tertarik untuk melakukan penelitian dengan judul "Pengaruh Disiplin Kerja, Motivasi Kerja, dan Lingkungan Kerja Terhadap Kinerja Pegawai Badan Pendapatan Pengelolaan Keuangan dan Aset Daerah Kabupaten Gresik”.

\section{Hipotesis}

H1: Diduga ada pengaruh disiplin kerja terhadap kinerja pegawai Badan Pendapatan Pengelolaan Keuangan dan Aset Daerah Kabupaten Gresik.

H2: Diduga ada pengaruh motivasi kerja terhadap kinerja pegawai Badan Pendapatan Pengelolaan Keuangan dan Aset Daerah Kabupaten Gresik

H3: Diduga ada pengaruh lingkungan kerja terhadap kinerja pegawai Badan Pendapatan Pengelolaan Keuangan dan Aset Daerah Kabupaten Gresik 
H4: Diduga ada pengaruh disiplin kerja, motivasi kerja, lingkungan kerja secara simultan terhadap kinerja pegawai Badan Pendapatan Pengelolaan Keuangan dan Aset Daerah Kabupaten Gresik

\section{METODE PENELITIAN}

\section{Populasi dan Sampel}

Populasi dalam penelitian ini adalah pegawai tetap Badan Pendapatan Pengelola Keuangan, dan Aset Daerah Kabupaten Gresik yang berjumlah 90 orang (sumber : bagian Kepegawaian, Oktober 2016).

Dalam penelitian ini, pengambilan sampel menggunakan teknik Probability Sampling jenis Propotionate stratified random sampling yang merupakan teknik pengambilan sampel dilakukan dengan secara acak tanpa memperhatikan strata yang ada dalam populasi (Sugiyono, 2013;82). Menurut Sugiyono $(2013 ; 86)$ menyatakan bahwa jumlah sampel dari populasi tertentu yang dikembangkan dari Isaac dan Michael, jika populasi 90 orang dan tingkat kesalahan 5\% maka sampel yang digunakan adalah 72 responden

\section{Definisi Operasional}

\section{Disiplin (X1)}

Disiplin diartikan sebagai penilaian responden terhadap ketaatan dalam melaksanakan tugasnya sesuai dengan tanggung jawab yang diberikan. Dengan indikator sebagai berikut:

a. Ketaatan terhadap ketentuan masuk, pulang dan jam istirahat.

b. Ketaatan terhadap peraturan dasar tentang berpakaian dan bertingkah laku dalam pekerjaan.

c. Ketaatan terhadap prosedur operasional standar (SOP) dalam melaksanakan pekerjaan.

2. Motivasi Kerja (X2)

Motivasi diartikan sebagai penilaian responden terhadapsuatu faktor yang mendorong seseorang untuk menyelesaikan tugas yang diemban. Dengan indikator sebagai berikut:

a. Existence needs : kebutuhan ini berhubungan dengan fisik dari eksistensi pegawai.

b. Related needs : kepuasan dalam berinteraksi dalam lingkungan kerja.

c. Growth needs : kebutuhan untuk mengembangkan dan meningkatkan pribadi.

3. Lingkungan Kerja(X3)

Lingkungan Kerja diartikan sebagai penilaian responden terhadap segala sesuatu yang ada disekitar karyawan yang mempengaruhi dalam melaksanakan tugas yang diemban. Dengan indikator sebagai berikut: a. Lampu penerangan tempat kerja

b. Jendela tempat kerja

c. Tata warna

d. Dekorasi

e. Bunyi musik

f. Suhu udara

4. Kinerja Pegawai Negeri Sipil (Y)

Kinerja diartikan sebagai penilaian pegawai terhadap hasil kerja yang dicapai oleh pegawai sesuai dengan standart dan kriteria yang ditetapkan, meliputi aspek sebagai berikut :

a. Sasaran Kerja Pegawai, Sasaran Kerja Pegawai adalah penilaian responden terhadap rencana kerja dan target responden sebagaimana yang dimaksud : kualitas, waktu, biaya.

b. Perilaku Kerja, Perilaku kerja adalah penilaian responden terhadap setiap tingkah laku, sikap atau tindakan yang dilakukan oleh responden atau tidak melakukan sesuatu yang seharusnya dilakukan sesuai dengan ketentuan peraturan perundang-undangan : integritas, komitmen, kepemimpinan

\section{Metode Pengumpalan Data}

Dalam penelitian ini metode pengumpulan data yang digunakan adalah dengan cara mengumpulkan data-data dari hasil kuisioner yang berkaitan dalam penelitian.

\section{HASIL DAN PEMBAHASAN \\ Uji Validitas \& Reliabilitas \\ Uji Validitas}

Dari hasil uji validitas instrumen semua variabel didapatkan rhitung > rtabel 0,2319. Jadi seluruh butir pernyataan dari variabel independen maupun dependen terbukti valid.

\section{Uji Reliabilitas}

Berdasarkan tabel 4.10 menunjukkan bahwa masing-masing variabel nilai nilai Cronbach Alpha lebih besar dari 0,70. Dengan demikian dapat disimpulkan bahwa alat ukur yang digunakan dalam penelitian ini adalah reliabel.

\section{Analisis Uji Asumsi Klasik}

Uji Multikolinearitas

Tabel 4.10 Koefisien tolerance value dan VIF

\begin{tabular}{|c|l|c|c|}
\hline $\begin{array}{c}\text { Variabel } \\
\text { Bebas }\end{array}$ & $\begin{array}{c}\text { Tolerance } \\
\text { Value }\end{array}$ & VIF & Keterangan \\
\hline Disipin & 0,838 & 1.194 & $\begin{array}{c}\text { Nonmultikoli } \\
\text { nieritas }\end{array}$ \\
\hline Motivasi & 0,819 & 1.221 & $\begin{array}{c}\text { Nonmultikoli } \\
\text { nieritas }\end{array}$ \\
\hline $\begin{array}{c}\text { Lingkun } \\
\text { gan Kerja }\end{array}$ & 0,742 & 1.348 & $\begin{array}{c}\text { Nonmultikol } \\
\text { inieritas }\end{array}$ \\
\hline
\end{tabular}

Dari hasil pengelolaan data diperoleh nilai tolerance value lebih besar dari 0,1 dan VIF lebih kecil dari 10, maka dapat disimpulkan 
bahwa model regresi tidak memiliki masalah multikolinearitas.

\section{Uji Autokorelasi}

Tabel 4.13 Nilai Durbin Watson

\begin{tabular}{|c|c|c|}
\hline & Nilai & Keterangan \\
\hline $\begin{array}{c}\text { Durbin } \\
\text { Watson }\end{array}$ & 1.944 & Tidak ada autokorelasi \\
\hline
\end{tabular}

Berdasarkan tabel 4.13 diatas menunjukkan bahwa nilai Durbin Watson 1.944 terletak antara batas atas du (1.705) dan 4-du (2.295), maka dapat di simpulkan tidak terdapat autokorelasi pada model regresi ini.

\section{Uji Heteroskedastisitas}

Tabel 4.12 Nilai Uji Glejser

\begin{tabular}{|c|c|c|}
\hline VARIABEL & Sig. & Kesimpulan \\
\hline $\begin{array}{c}\text { Disiplin } \\
\text { Kerja (X1) }\end{array}$ & 0.19 & $\begin{array}{c}\text { tidak terdapat gejala } \\
\text { heteroskedastisitas }\end{array}$ \\
\hline $\begin{array}{c}\text { Motivasi } \\
\text { (X2) }\end{array}$ & 0.68 & $\begin{array}{c}\text { tidak terdapat gejala } \\
\text { heteroskedastisitas }\end{array}$ \\
\hline $\begin{array}{c}\text { Lingkungan } \\
\text { Kerja (X3) }\end{array}$ & 0.26 & $\begin{array}{c}\text { tidak terdapat gejala } \\
\text { heteroskedastisitas }\end{array}$ \\
\hline
\end{tabular}

Berdasarkan tabel 4.12 diatas menunjukkan bahwa Nilai Uji Glejser Disiplin kerja (X1) 0.191, Motivasi (X2) 0.681 dan Lingkungan Kerja (X3) 0.268 hal tersebut menunjukan tidak terdapat gejala heteroskedastisitas karena hasil sig. > 0.05

\section{Uji Normalitas}

Gambar 4.2 Hasil Uji Normalitas

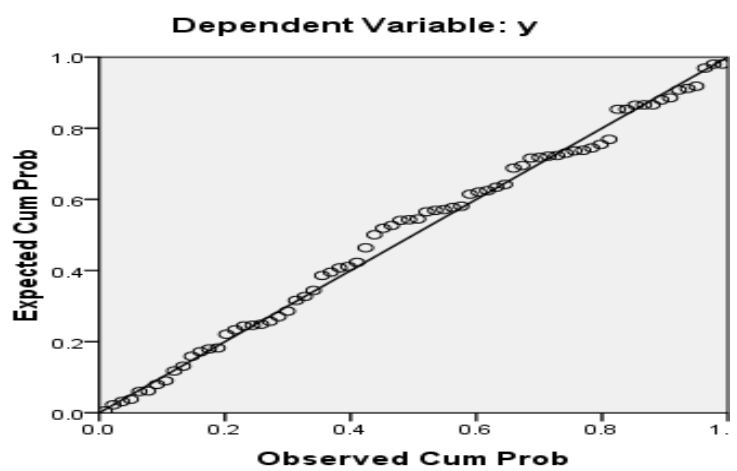

Gambar 4.2 menunjukkan bahwa grafik Normal P-P Plot of Regression Standardized Residual menggambarkan penyebaran data disekitar garis diagonal dan penyebarannya mengikuti arah garis diagonal grafik tersebut, maka model regresi yang digunakan dalam penelitian ini memenuhi asumsi normalitas.

\section{Analisis Data}

Analisis Regresi Linear Berganda

Analisis ini digunakan untuk mengetahui apakah variabel Disiplin, Motivasi dan Lingkungan Kerja berpengaruh terhadap Kinerja pegawai tetap di Badan Pendapatan Pengelola Keuangan, dan Aset Daerah Kabupaten Gresik
Tabel 4.14

Analisis Regresi Linier Berganda

\begin{tabular}{|c|c|c|c|c|c|c|}
\hline \multirow{2}{*}{\multicolumn{2}{|c|}{ Model }} & \multicolumn{2}{|c|}{\begin{tabular}{|l} 
Unstandardized \\
Coefficients
\end{tabular}} & \multirow{2}{*}{\begin{tabular}{|l}
$\begin{array}{l}\text { Standardiz } \\
\text { ed } \\
\text { Coefficients }\end{array}$ \\
Beta \\
\end{tabular}} & \multirow[b]{2}{*}{$\mathrm{T}$} & \multirow[b]{2}{*}{ Sig. } \\
\hline & & B & Std. Error & & & \\
\hline 1 & (Constant) & $4^{6.16}$ & 2.170 & & 2.841 & .006 \\
\hline & Disiplin & .602 & .142 & .406 & 4.239 & .000 \\
\hline & Motivasi & .495 & .161 & .298 & 3.074 & .003 \\
\hline & $\begin{array}{l}\text { Lingkungan } \\
\text { Kerja }\end{array}$ & .183 & .089 & .209 & 2.053 & .044 \\
\hline
\end{tabular}

$Y=6,164+0,602 X_{1}+0,495 X_{2}+0,183 X_{3}$

1. Nilai konstanta 6,164 menunjukan apabila Disipilin (X1), Motivasi (X2), Lingkunga Kerja (X3), bernilai 0, maka Kinerja Pegawai tetap di Badan Pendapatan Pengelola Keuangan, dan Aset Daerah Kabupaten Gresik (Y) adalah sebesar 6,164 . Hal ini berarti tanpa adanya atau sebelum variabel Disipilin (X1), Motivasi (X2), Lingkungan Kerja (X3) dalam perusahaan maka besarnya Kinerja Pegawai tetap di Badan Pendapatan Pengelola Keuangan, dan Aset Daerah Kabupaten Gresik 6,164.

2. Jika Disipilin (X1) mengalami perubahan, maka Y akan meningkat sebesar 0,60, dengan anggapan Motivasi (X2) dan Lingkungan Kerja (X3) tetap.

3. Jika Motivasi (X2) mengalami perubahan, maka $\mathrm{Y}$ akan meningkat sebesar 0,495, dengan anggapan Disipilin (X1) dan Lingkungan Kerja (X3) tetap.

4. Jika Lingkungan Kerja (X3) mengalami perubahan, maka $\mathrm{Y}$ akan meningkat sebesar 0,183, dengan anggapan Disiplin (X1) dan Motivasi (X2) tetap.

Koifisien determinasi ( R2 ) dan koifisien korelasi ganda

Tabel 4.15 Koefisien determinasi $\left(\mathbf{R}^{2}\right)$

\begin{tabular}{|c|l|c|c|c|c|}
\hline $\begin{array}{c}\text { Mo } \\
\text { del }\end{array}$ & $R$ & $\begin{array}{c}R \\
\text { Square }\end{array}$ & $\begin{array}{c}\text { Adjusted } \\
\text { R Square }\end{array}$ & $\begin{array}{c}\text { Std. Error of } \\
\text { the Estimate }\end{array}$ & $\begin{array}{c}\text { Durbin- } \\
\text { Watson }\end{array}$ \\
\hline 1 & $.690(\mathrm{a})$ & .477 & .454 & 2.109 & 1.944 \\
\hline
\end{tabular}

1. Berdasarkan data diatas maka diperoleh nilai Adjusted $\mathrm{R}$ Square $=0,454$ dapat dikatakan bahwa perubahan variabel terikat Kinerja Pegawai (Y) sebesar 45.4 $\%$ disebabkan oleh variabel Disiplin $\left(\mathrm{X}_{1}\right)$, Motivasi $\left(\mathrm{X}_{2}\right)$ dan Lingkungan Kerja $\left(\mathrm{X}_{3}\right)$ sedangkan selebihnya sebesar $54,6 \%$ 
disebabkan oleh faktor-faktor lain diluar variabel tersebut.

2. Berdasarkan data diatas maka diperoleh nilai $\mathrm{R}$ Square $=0,477$ artinya bahwa variabel Disiplin $\left(\mathrm{X}_{1}\right)$, Motivasi $\left(\mathrm{X}_{2}\right)$ dan Lingkungan Kerja $\left(\mathrm{X}_{3}\right)$ mampu menjelaskan perubahan dalam variabel terikat Kinerja Pegawai (Y) sebesar 47.7 $\%$, sedangkan selebihnya sebesar 52,3\% disebabkan oleh faktor-faktor lain diluar variabel tersebut.

3. $\mathrm{R}=0,690$ artinya kuatnya hubungan antar variabel independen (X) bersama-sama terhadap variabel $(\mathrm{Y})$ yaitu $69, \%$.

\section{Uji Hipotesis}

Uji t (Parsial)

Tabel 4.16 Hasil Analisis Uji Koefisien

\begin{tabular}{|c|c|c|c|c|c|c|}
\hline \multirow[b]{2}{*}{ Mode } & & \multicolumn{2}{|c|}{$\begin{array}{l}\text { Unstandardized } \\
\text { Coefficients }\end{array}$} & \multirow{2}{*}{$\begin{array}{c}\begin{array}{c}\text { Standardized } \\
\text { Coefficients }\end{array} \\
\text { Beta } \\
\end{array}$} & \multirow[b]{2}{*}{$\mathrm{T}$} & \multirow[b]{2}{*}{ Sig. } \\
\hline & & $\mathrm{B}$ & Std. Error & & & \\
\hline \multirow[t]{4}{*}{1} & $\begin{array}{l}\text { (Const } \\
\text { ant) }\end{array}$ & 6.164 & 2.170 & & 2.841 & .006 \\
\hline & $\mathrm{X} 1$ & .602 & .142 & .406 & 4.239 & .000 \\
\hline & $\mathrm{X} 2$ & .495 & .161 & .298 & 3.074 & .003 \\
\hline & $\mathrm{X} 3$ & .183 & .089 & .209 & 2.053 & .044 \\
\hline
\end{tabular}

Dari table dapat dijelaskan bahwa $\mathrm{t}$ hitung variabel disiplin $\left(\mathrm{X}_{1}\right)$ 4,239 lebih besar daripada $\mathrm{t}$ tabel 1,994 maka Ho ditolak $\mathrm{Ha}$ diterima. Dengan demikian hasil perhitungan statistik menunjukan bahwa secara parsial variabel Disiplin $\left(\mathrm{X}_{1}\right)$ berpengaruh signifikan terhadap Kinerja Pegawai tetap di Badan Pendapatan Pengelola Keuangan, dan Aset Daerah Kabupaten Gresik

Uji F (Simultan)

Tabel 4.17 Uji Secara Simultan ( Uji F )

\begin{tabular}{|rr|r|r|r|r|r|}
\multicolumn{1}{|c|}{ ANOVA $^{\mathrm{b}}$} \\
\hline Model & & \multicolumn{1}{c|}{$\begin{array}{c}\text { Sum of } \\
\text { Squares }\end{array}$} & Df & $\begin{array}{c}\text { Mean } \\
\text { Square }\end{array}$ & F & Sig. \\
\hline 1 & Regression & 275.572 & 3 & 91.857 & 20.654 & $.000=$ \\
& Residual & 302.428 & 68 & 4.447 & & \\
& & & & & & \\
& Total & 578.000 & 71 & & & \\
\hline
\end{tabular}

Dari tabel diatas terlihat bahwa nilai regresi memiliki tingkat signifikansi 0,00 nilai ini lebih kecil dari 0,05 atau nilai signifikansi $<\alpha$ dan F hitung memiliki nilai 20,654 sedangkan $\mathrm{F}$ tabel memiliki nilai 2,736 ini berarti $\mathrm{F}$ hitung > F tabel, sehingga Ho ditolak dan Ha diterima, artinya secara simultan berpengaruh signifikan Disiplin kerja (X_1), Motivasi (X_2) dan lingkungan kerja (X_3) terhadap Kinerja pegawai tetap di Badan Pendapatan Pengelola Keuangan, dan Aset Daerah Kabupaten Gresik (Y).

\section{KESIMPULAN}

Berdasarkan hasil pengolahan data dalam penelitian ini dapat ditarik kesimpulan sebagai berikut :

1. Pengujian hipotesis pada uji parsial (uji t) memberikan hasil bahwa variabel Disiplin (X1) berpengaruh dan signifikan terhadap Kinerja Pegawai Tetap di Badan Pendapatan Pengelola Keuangan, dan Aset Daerah Kabupaten Gresik.

2. Pengujian hipotesis pada uji parsial (uji t) memberikan hasil bahwa variabel Motivasi (X2) berpengaruh dan signifikan terhadap Kinerja Pegawai Tetap di Badan Pendapatan Pengelola Keuangan, dan Aset Daerah Kabupaten Gresik.

3. Pengujian hipotesis pada uji parsial (uji t) memberikan hasil bahwa variabel Lingkungan Kerja (X3) berpengaruh dan signifikan terhadap Kinerja Pegawai Tetap di Badan Pendapatan Pengelola Keuangan, dan Aset Daerah Kabupaten Gresik.

4. Pengujian hipotesis pada uji simultan (uji F) memberikan hasil bahwa variabel Disiplin, Motivasi dan Lingkungan Kerja berpengaruh dan signifikan terhadap Kinerja Pegawai Tetap di Badan Pendapatan Pengelola Keuangan, dan Aset Daerah Kabupaten Gresik.

\section{Saran}

Berdasarkan hasil analisis, pembahasan, dan kesimpulan penelitian, maka rekomendasi dari peneliti dapat diberikan sebagai berikut :

\section{Bagi Aspek Manajerial}

1. Melihat variabel Disiplin memiliki nilai terendah pada item taat terhadap peraturan keBadanan tentang berpakaian dan bertingkah laku dalam bekerja, sebaiknya Manajemen Badan Pendapatan Pengelola Keuangan, dan Aset Daerah Kabupaten Gresik harus memberikan peraturan berpakaian sesuai hari kerja dan memberikan pelatihan bertingkah laku yang baik dalam bekerja. supaya kinerja pegawai bisa maksimal.

2. Melihat variabel Motivasi memiliki nilai terendah pada item kebutuhan untuk mengembangkan dan meningkatkan pribadi sebaiknya Manajemen Badan Pendapatan Pengelola Keuangan, dan Aset Daerah Kabupaten Gresik harus lebih memperhatikan pegawai dengan memberikan penyuluhan dan pelatihan secara bertahap supaya pegawai Badan Pendapatan Pengelola Keuangan, dan Aset 
Daerah Kabupaten Gresik merasa lebih diperhatikan dan bisa meningkatkan motivasi dalam pencapaian kinerja.

3. Melihat variabel Lingkungan Kerja memiliki nilai terendah pada item bahwa jendela tempat kerja dapat mempengaruhi dalam menyelesaikan pekerjaan sebaiknya Manajemen Badan Pendapatan Pengelola Keuangan, dan Aset Daerah Kabupaten Gresik melakukan perbaikan jendela jendela yang sudah rusak atau tidak layak pakai, sehinggan pegawai merasa nyaman dan bisa meningkatkaan kinerja.

\section{Bagi Peneliti Selanjutnya}

Bagi peneliti selanjutnya hasil penelitian ini dapat digunakan sebagai referensi bagi peneliti selanjutnya dengan memperbanyak jumlahjumlah variabel-variabelnya dan menggunakan teknik analisis yang berbeda.

\section{DAFTAR PUSTAKA}

Afandi, Pandi, 2016, Concept And Indicator Human Resourcer Management For Management Researth, Cetakan $\mathrm{Ke}$ 1, Cv Budi Utama Yogyakarta

Bangun, Wilson, 2012, Manajemen Sumber Daya Manusia, Erlangga, Jakarta.

Ghozali, Imam, 2013, Aplikasi Analis Multivariate Dengan Program IBM SPSS 21, Edisi 2, Universitas Diponegoro, Semarang.

Hasibuan, Malayu S.P., 2011, Manajemen Sumber Daya Manusia Edisi Revisi, Cetakan Kelima Belas, Bumi Aksara, Jakarta.

Mangkunegara, Anwar Prabu, 2011, Manajemen Sumber Daya manusia Perusahaan, PT. Remaja Rosdakarya.

Rivai, Veithzal dan Ella Jauvani Sagala, 2013, Manajemen Sumber Daya Manusia Untuk Perusahan Dari Teori Ke Praktik, Cetakan Ke-5, PT Rajagrafindo Persada.

Sedarmayanti, 2009, Sumber Daya Manusia dan Produktivitas Kerja, cetakan ke-3 CV Mandar Maju, Bandung.

Sofyandi, Herman, 2008, Manajemen Sumber Daya Manusia, Edisi Pertama, Graha Ilmu, Yogyakarta.

Sugiyono, 2013, Metode Penelitian Kuantitatif, Kualitatif, Dan $R \& B$, Cetakan Ke-19, Alfabeta, Bandung.

Sutrisno, Edi, 2014, Manajemen Sumber Daya Manusia, Cetakan Ke-6, Kencana Prenada Media Grup, Jakarta.
Wirawan, 2009, Evaluasi Kinerja Sumber Daya Manusia Teori Aplikasi Dan Penelitian, Salemba Empat, Jakarta.

Sukoco 2011 Pengaruh Lingkungan Kerja Terhadap Kinerja Karyawan Dibagian Produksi PT. Temprina Media Grafika Surabaya. Skripsi. Gresik : Program Studi Manajemen, Universitas Muhammadiyah Gresik.

Laksono, Cahyo, 2015, Pengaruh Disiplin Kerja, Penempatan Kerja dan Motivasi Kerja Terhadap Kinerja Pegawai di PT Arifin Sidayu Gresik. Skripsi. Gresik : Program Studi Manajemen, Universitas Muhammadiyah Gresik

Zahid, Yakhya, 2015, Pengaruh Kedisiplinan dan Motivasi Kerja Terhadap Kinerja Pegawai di Dinas Tenaga Kerja Pemerintah Kabupaten Gresik.

Skripsi. Gresik : Program Studi Mnajemen, Universitas Muhammadiyah Gresik.

Yakub, Suardi, Anton Tulim, Suharsil, 2014, Pengaruh Disiplin Kerja, Pendidikan Dan Pelatihan Terhadap Kinerja Pegawai Pada PT Kertas Kraft Aceh (PERSERO), Jurnal SAINTIKOM, Vol. 13 No. 3, September, hal 227-238.

Undang- Undang Nomor 43 Tahun 1999 Tentang Perubahan Atas Undang Undang Nomor 8 Tahun 1974 tentang Pokok-Pokok Kepegawaian. Peraturan Pemerintah Nomor 46 Tahun 2011 Tentang Penilaian Prestasi Kerja Pegawai Negeri Sipil.

Peraturan Pemerintah Nomor 53 Tahun 2012 Tentang Disiplin Pegawai Negeri Sipil.

Peraturan Pemerintah Republik Indonesia Nomor 69 Tahun 2010 Tentang Tata Cara Pemberian dan Pemanfaatan Insentif Pemungutan Pajak Daerah Dan Retribusi Daerah. 